OPEN ACCESS

Edited by:

Janne Mikael Lundén University of Helsinki, Finland

Reviewed by:

John J. Maurer, University of Georgia, United States Cangliang Shen,

West Virginia University, United States

${ }^{*}$ Correspondence: Steven C. Ricke sricke@uark.edu

Specialty section

This article was submitted to Agro-Food Safety, a section of the journal Frontiers in Sustainable Food Systems

Received: 21 June 2019

Accepted: 22 August 2019 Published: 04 September 2019

Citation:

Rothrock MJ Jr, Gibson KE, Micciche AC and Ricke SC (2019) Pastured Poultry Production in the United States: Strategies to Balance

System Sustainability and Environmental Impact. Front. Sustain. Food Syst. 3:74. doi: 10.3389/fsufs. 2019.00074

\section{Pastured Poultry Production in the United States: Strategies to Balance System Sustainability and Environmental Impact}

\author{
Michael J. Rothrock Jr. ${ }^{1}$, Kristen E. Gibson ${ }^{2}$, Andrew C. Micciche ${ }^{2}$ and Steven C. Ricke ${ }^{2 \star}$ \\ 1 USDA-ARS, Egg Safety and Quality Research Unit, U.S. National Poultry Research Center, Athens, GA, United States, \\ ${ }^{2}$ Food Science Department, Center for Food Safety, University of Arkansas, Fayetteville, AR, United States
}

Nutrient and pathogen pollution are the leading causes of water quality impairment in lakes, reservoirs, and rivers in the United States. Dissemination of these contaminants can result in eutrophication of freshwater resources and pose a risk to public health through recreational contact and degradation of waters used as drinking water sources. Agricultural production practices, both crop and animal, have been identified as sources of excess nutrients and microbial pathogens contributing to freshwater pollution. In the U.S., commercial meat poultry production has been targeted as a source of both excess nutrients, especially phosphorus, and fecal indicator bacteria (FIB) in regional watersheds. Recently, there has been an increase in pastured poultry operations where chickens have access to fresh pasture on a daily basis. However, few studies have explored the environmental sustainability of these types of poultry production systems. In the case of pastured poultry systems in close proximity to watersheds, there is a need to better understand potential environmental impacts in order to implement sustainable and cost-effective practices. The identification of such environmental and economic benefits would complement the mission and objectives of farmers using pastured poultry production systems and may add more value to their product. This review will focus on potential mitigation strategies to enhance environmental sustainability and provide economic benefit to small scale pastured poultry operations.

Keywords: pastured poultry production, environmental impact, vegetative buffer strip, economic impact, nutrient runoff

\section{INTRODUCTION}

An important component of any sustainable animal production system is its interaction with the surrounding environment (Boggia et al., 2010). Nutrients, pathogens, and sediment pollution remain the leading causes of environmental quality impairment in lakes, reservoirs, and rivers in the United States and animal production can play a role in watershed pollution (Carpenter et al., 1998; Arnone and Walling, 2007; Wong et al., 2018). The dispersal of these contaminants can result in eutrophication of freshwater resources, as well as pose a risk to public health through recreational contact and degradation of waters used in drinking water sources (Lapointe et al., 2015). In 2013, 42 drinking water associated outbreaks occurred in the US resulting in 1,006 cases of illness and 13 deaths primarily due to Legionella, Cryptosporidium, and Giardia (Braeye et al., 2015). Poultry 
farms in particular have been shown to cause increases in copper, zinc, potassium, and other nutrients concentrations into nearby rivers due to runoff of poultry litter (DeLaune and Moore, 2016; Sharpley et al., 2018).

Agricultural production practices, both crop and animal, have been identified as sources of excess nutrients and microorganisms contributing to freshwater pollution (Nayak et al., 2015; Evans et al., 2019). In states such as Arkansas, the land application of manure generated by confined poultry operations has been identified as a source of both excess nutrients, especially phosphorous, and fecal indicator bacteria (FIB) in regional watersheds (Ismail et al., 2016; Sharpley et al., 2016). Watershed contamination from local farming systems has affected both surface (Edge et al., 2012; Vereen et al., 2013) and groundwaters (Gallay et al., 2006; Frey et al., 2015), and has been linked to human illness within and near these farming communities (McEwen et al., 2006; Gilpin et al., 2008). One such major recent example occurred in Walkerton, Ontario, Canada, where a waterborne outbreak of Campylobacter jejuni, C. coli, and Escherichia coli O157:H7 occurred, and phenotypic/genotypic characterizations attributed specific subtypes to a single local farm (Clark et al., 2003).

In the past decade, there has been an increased attention on pastured poultry operations, where chickens have constant access to pasture, and are moved onto fresh pasture daily (Mench et al., 2011; Rothrock et al., 2016). Pastured poultry is defined as birds given access to a fenced in pasture to graze on with potential for feed supplements and the birds typically reside in a mobile chicken coop at night (Pitesky, 2017). Free-range poultry is a loose term for any system that provides limited access to a fenced in outdoor area (Pitesky, 2017). Similar to conventionally-raised poultry, pathogens have been detected in the gastrointestinal tract of birds raised on pasture (Trimble et al., 2013). Fecal material from poultry litter deposited on pasture may contain these pathogens and possibly enter nearby lakes and streams without appropriate buffers in place (Metcalf et al., 2014). Some mitigation strategies have been developed for the reduction of nutrient and microbial runoff in pastured poultry systems including pasture management recommendations and the addition of vegetative buffers in high runoff areas (Adrizal et al., 2008; Pilon et al., 2017). These plant-based vegetative buffers are typically placed between pastures and bodies of water in order to reduce runoff (Tate et al., 2006).

In addition to understanding the pastured poultry production environment, there is a need to develop economic tools that would allow producers to augment better financial decisions concerning adopting best management practices. Environmental survey data is important to pastured poultry producers by providing them critical information concerning the ecological impacts of these systems and practical and economical strategies to reduce any potential harmful impacts (Sossidou et al., 2011). Along with survey data, budgeting tools specific to pastured poultry producers are needed to enable them to make the best decisions for their production system based on the cost and benefit of choices related to the selection of meat type bird, production practices, and pasture management. Also, producers need information on how to best house and rotate their pastured poultry to obtain the most from the natural fertilizer produced by the birds (Grandin, 2019). Ultimately, the objective of this review is to assess the potential environmental and pathogen impacts of pastured poultry production systems along with strategies to increase the sustainability and profitability of these systems. Overall, this review addresses current environmental practices used by pastured poultry producers and discusses strategies to improve these production systems to enhance environmental stewardship. This review will also investigate the economic impacts of environmental management within pastured poultry production systems.

\section{PASTURED POULTRY PRODUCTION-CURRENT MARKET TRENDS}

Pastured poultry farms across the U.S. either allow birds complete free-range on pasture or raise them in small, open-air moveable pens where birds have access to fresh pasture daily. The demand for free-range or pastured poultry products has increased, and these types of production systems are being adopted by small to medium-sized farms ( $<4,000$ birds per year) (Elkhoraibi et al., 2017; Knight et al., 2017). In some states, such as Maine, these small scale operations have increased by over 65\% from 214 in 2012 to 355 in 2017 (Knight et al., 2017). The March 2019 average retail sale price of pasture-based chicken breast meat is $\$ 12.50 / \mathrm{lb}$ compared to $\$ 2.37 / \mathrm{lb}$ for conventional breast meat (Foster, 2019; USDA/NASS, 2019). Moreover, the U.S. market price for all-natural and organic broilers averages 200\% more than conventional broilers (Van Loo et al., 2011; AschemannWitzel and Zielke, 2017), indicating the potential profitability of pastured poultry production systems.

Currently, the actual number of pastured poultry producers in the U.S. is unknown as no databases are available through the USDA National Agricultural Statistics Service; however, 750 farms are currently registered to the American Pasture Poultry Production Association (APPPA) (American Pasture Poultry Production Association (APPPA), 2019). This type of production system is considered by some as a more sustainable alternative to conventional broiler production (Sossidou et al., 2011; Castellini et al., 2012). Along with promoting good stewardship of the nation's natural resources, there are potential economic impacts of setting recommendations for best practices to be implemented by pastured poultry producers. Most pastured poultry producers are considered small family farms, which are defined by the USDA as farms that sell $<\$ 100,000$ in agricultural products annually (USDA/ERS, 2011). In 2017, half the U.S. farms had livestock sales of $<\$ 10,000$ (Kassel, 2018). Therefore, recommended best practices must also be economically feasible as well as promote the food safety of the final product.

\section{POULTRY PRODUCTION AND ENVIRONMENTAL IMPACT-GENERAL CHARACTERISTICS}

The majority of research involving poultry production and environmental impacts (e.g., transport of nutrients and pathogens to surface and groundwater resources) has focused 
on conventional production systems. Issues surrounding conventional systems primarily arise from the over application of spent poultry litter to agricultural lands, resulting in runoff of excess nutrients, specifically phosphorus, which can be detrimental to nearby surface water resources (Pierson et al., 2001; Sharpley et al., 2007). This has been an especially sensitive issue in regions such as Northwest Arkansas where the rapid growth of confined broiler poultry operations and the long-term application of produced litter on area pastures has led to an increase in soil phosphorus and the potential for its loss in runoff (Slaton et al., 2004; Sharpley et al., 2009). Microbial source tracking (MST) has also indicated that poultry litter, which contains fecal material, can impact watersheds through runoff (Kobayashi et al., 2013). Gibson et al. (2017) found that during heavy rain events, the White River and Beaver Lake could experience E. coli levels exceeding 126 most probable number $(\mathrm{MPN}) / 100 \mathrm{~mL}$, which is the highest level acceptable for the river to be considered safe for primary recreational contact such as swimming. In addition, during these events, a poultry fecal marker targeting a poultry-specific Brevibacterium gene was more commonly detected. This indicates that during rain events nearby runoff from poultry farms or agricultural lands utilizing poultry litter as fertilizer may be contaminating the local watershed. Similarly, Weidhaas et al. (2011) investigated the presence of another poultry-specific Brevibacterium marker gene in the Illinois River Watershed. The authors found that the watershed was likely contaminated by poultry litter, and this co-varied with FIB as well as nutrient runoff of arsenic, copper, phosphorus, and zinc. Combined with increased nutrient inputs to recreational and drinking waters of Oklahoma, these findings led to several lawsuits between Oklahoma entities and Arkansas poultry integrators in the Eucha-Spavinaw and Illinois River Watersheds (DeLaune et al., 2006; Eilperin, 2006). As a result of this litigation and the increased awareness of the general public on sustainability issues and food source choices, pastured poultry production has steadily gained interest by consumers. Environmental impacts resulting in deterioration of both nearby surface and ground water resources have also been reported in Georgia and the Delmarva Peninsula-areas of high density, conventional poultry production (Sims, 1997; Pew Environment Group, 2011).

\section{MITIGATION OF PATHOGENS IN PASTURED POULTRY PRODUCTION}

The prevalence of pathogens such as Campylobacter and Salmonella in pastured poultry production were summarized in Van Loo et al. (2012) and Micciche et al. (2018a). Both indicate that some studies report higher concentrations and prevalence of pathogens in pasture production than in conventionally raised birds. For instance, Avrain et al. (2003) found that $80 \%$ of the ceca of free-range birds tested positive for Campylobacter compared to $57 \%$ for conventionally-reared birds. Other studies found free-range and pasture flock ceca and fecal material to contain Campylobacter at a prevalence of $70-100 \%$ in the birds tested (Colles et al., 2008; Esteban et al., 2008; Hanning et al.,
2010). Salmonella prevalence of $16-31 \%$ in pasture poultry production were also identified, while the USDA reports the 2014 prevalence of Salmonella in conventional rearing to be 3.7\% (Bailey and Cosby, 2005; Siemon et al., 2007; Melendez et al., 2010). Still, other studies have found lower prevalence of Salmonella and Campylobacter in pasture production compared to conventionally raised systems (Hoogenboom et al., 2008; Lestari et al., 2009; Alali et al., 2010; Van Loo et al., 2012). One potential reason for this variation in pathogen concentration in different pasture and free-range flocks is their potential contact with wild birds, rodents, and other vectors harboring these bacteria, which will vary from flock to flock and depend on factors such as geography, temperature, and wildlife prevention management (Berg, 2001; Hanning et al., 2010).

Regardless of the pathogen variability within pastured poultry production, there is potential for pathogens to be present in fecal material that can then be deposited on the pasture (Vories et al., 2001; Scott et al., 2011). Pre-harvest pathogen mitigation strategies have mainly focused on feed amendments or modulations and have been extensively discussed by Micciche et al. (2018a,b), Kim et al. (2019), Ricke (2018), Rothrock et al. (2019), Dittoe et al. (2018), and Gast (2007). These include, but are not limited to, prebiotics, probiotics, synbiotics, phage therapy, organic acids, and fiber. However, less attention has been given to physical barriers such as vegetative buffers.

Vegetative buffers are strips of plant life between livestock pastures and bodies of water with the express purpose of reducing agricultural runoff, including pathogens (Dosskey, 2002; Tate et al., 2006). They are also known as grass filters, vegetative strips, and filter strips (Chaubey et al., 1995). The U.S. Environmental Protection Agency has stated most pathogen contamination of water bodies is due to manure production from animal feeding operations (U.S. Environmental Protection Agency, 2010; Bradford et al., 2013). Metcalf et al. (2014) evaluated runoff on simulated plots with $0,1,2$, or 4 tons of poultry litter/acre. Simulated rainfall was applied for $\sim 1$ h a week for 3 weeks, and runoff was evaluated for E. coli, Enterococcus, Salmonella, and Campylobacter. No Campylobacter counts were detected. Salmonella was detected sporadically including in the untreated control plots leading the authors to conclude that the presence of Salmonella may have been due to rodents or other outside sources and not the poultry litter. At day 1 of the experiment, colony forming units (CFU) of Enterococcus were significantly higher in the runoff of the 4 ton amended plots compared to the control with $5 \log \mathrm{CFU} / 100 \mathrm{~mL}$ vs. $3.7 \log$ CFU/100 mL, respectively. E. coli was also significantly higher in the 1 ton amended plot runoff on day 1 compared to the control (5.5 log CFU/100 mL vs. $3 \log$ CFU/100 mL). All other time points and treatments did not differ significantly from the control despite the average Enterococcus and E. coli populations being $\sim 1$ log higher in the poultry litter treatments suggesting considerable variability. However, an earlier study by Soupir et al. (2006) did find significant increases in E. coli in poultry litter amended runoff (4.3 log CFU/100 ml compared to $1 \log$ $\mathrm{CFU} / 100 \mathrm{~mL}$ in the control). These data were acquired $24 \mathrm{~h}$ after the litter was placed on the plot. Cow manure and liquid dairy manure were also investigated, and E. coli levels were higher 
in the manure treatments $(5.13 \log \mathrm{CFU} / 100 \mathrm{~mL}$ and $4.26 \log$ $\mathrm{CFU} / 100 \mathrm{~mL}$ ).

Limited studies have been performed evaluating the impact of vegetative buffers on reducing these bacterial runoff loads. By planting Carex secta, a New Zealand grass, between a nearby river and cattle pastures, Giardia prevalence was reduced in the body of water by $26 \%$ as reported by Winkworth et al. (2008). Investigations into ryegrass (Lolium perenne) found that it was not sufficient in reducing E. coli from liquid swine manure runoff compared to an unplanted plot of sandy loam soil (Fox et al., 2011). However, Parajuli et al. (2008) investigated the Upper Wakarusa watershed in Northeast Kansas and concluded that FIB in the body of water could be sufficiently reduced by applying vegetative filters on the edge of fields. Utilizing a soil and water assessment tool (SWAT) on 53 sub-basins, it was determined that vegetative buffer or filter $10 \mathrm{~m}$ deep reduced up to $57 \%$ of FIB, where $15 \mathrm{~m}$ reduced up to $80 \%$ and $20 \mathrm{~m}$ removed $99.9 \%$ of fecal bacteria. The sub-basin with the lowest fecal bacteria count had a $20 \mathrm{~m}$ of vegetative buffer and a count of $189 \mathrm{CFU} / 100 \mathrm{~mL}$. The sub-basin with the highest bacterial count had 5,460 CFU/100 mL.

Vegetative buffers have also been evaluated to prevent the spread of avian viruses between houses. Seven-week-old leghorn hens were placed in separate coops or houses. Control birds in the houses were given attenuated live vaccine strains of the Newcastle disease virus (NDV) (Burley et al., 2011). By day 7 in the control group, $29.17 \%$ of serum samples in the coops outside the houses were positive for NDV and this rose to $75 \%$ by day 17 . When vegetative buffers were in place these concentrations were significantly lower (16.67 and 65.22\%). The buffered vegetation consisted of silver grass clusters (Miscanthus floridulus), silver maple (Acer saccharinum), red oak (Quercus rubra), spike hybrid poplar (Populus deltoides $\times$ Populus nigra), black alder (Alnus glutinosa), and three hackberry (Celtis occidentalis), arborvitae (Thuja occidentalis), and Streamco willow (Salix purpurea). The buffers were $11 \mathrm{~m}$ in width by $12.8 \mathrm{~m}$ in depth with plants ranging from 1.6 to $2.1 \mathrm{~m}$. No study to date has evaluated the effect of using vegetative buffers to prevent pathogen contamination of the environment from pastured poultry operations. However, due to the reductive capability shown in other pastured livestock farms, their application may be appropriate and may be helpful for providing guidelines on how frequent mobile pens should be moved in a pasture to avoid buildup of nutrients and pathogens that can runoff into nearby watersheds.

\section{ENVIRONMENTAL IMPACT OF PASTURED POULTRY PRODUCTION SYSTEMS AND IMPROVEMENT STRATEGIES}

In contrast to conventional poultry systems, virtually no studies have been conducted on the potential environmental impacts of pasture poultry farms. A single study conducted by the University of Hawaii Cooperative Extension Service investigated the sustainability of pastured poultry production in Hawaii in 1999 (Fukumoto and Replogle, 1999). In this study, the authors modeled the potential nutrient cycling of a 1,000 broiler per year system on a single acre of pasture and concluded that pastured poultry production would result in enhanced forage production and improved animal performance. A pen (3.5 by 3 by $0.5 \mathrm{~m}$ ) containing 100 birds was moved daily for the first 3 weeks and twice during the fourth week of the study, while a second experiment was performed utilizing a larger pen (4 by 3 by $1 \mathrm{~m}$ ). The average carcass weight of the Cornish-Rock broilers was $2.5 \mathrm{~kg}$ in the second experiment compared to $1.7 \mathrm{~kg}$ in the first, which indicates that a larger grazing area produced larger birds and the breakeven point was $\$ 3.30 / \mathrm{kg}$ and $\$ 3.82 / \mathrm{kg}$ for the larger and smaller pens, respectively. Environmentally, the pasture regrowth patterns produced a dark green color grass that other livestock, such as cows, were averse to grazing on, but after 30 days the odor was reduced allowing for grazing to occur. The soil had nearly twice the crude protein concentration after grazing. Overall, the authors estimated that over a 1 year period, $12 \%$ of the recommended potassium and phosphorus level and $8 \%$ of the recommended nitrogen would be provided through raising birds. These estimates indicate that a properly managed pastured poultry operation would result in a decreased need for land application of fertilizers.

U.S. pastured poultry producers have a relatively greater level of freedom in their decisions about production systems, flock management, supplemental feed, and selection of meattype breeds compared to their conventional counterparts (Castellini et al., 2012). Because of the continuous outdoor aspect of the production system, pastured poultry can damage vegetation and cause buildup of nutrients and microorganisms, including human foodborne pathogens such as Campylobacter and Salmonella, on pastures if not managed properly (Fanatico, 2006). Therefore, it remains critical to evaluate the potential impacts of various pastured poultry production systems on the environment, including both nutrient and microbial runoff. In order to understand the transport of nutrients and pathogens from these smaller production systems, studies are needed to determine the amount of nutrients and pathogens in the pastures available for runoff into nearby surface waters. As the birds are raised on pasture, fecal matter is continuously excreted directly onto the field throughout the growing season, and thus, is not subjected to waste management practices, such as composting which is designed for the inactivation of pathogens (Ferguson et al., 2007). Movement of the pen mitigates this impact, but pasture rotation cycle may vary in length and is dependent on the size of the pasture relative to the size of the flock. Similar to phosphorus, microorganisms can absorb to soil and can be transported during erosion events associated with periods of heavy rainfall (Santamaría and Toranzos, 2003; Ferguson et al., 2007). Previous studies have linked rainfall event-related increases in pathogen concentrations in surface waters to animal fecal deposits on land (Atherholt et al., 1998). Pastured poultry represents a unique situation where flock management (e.g., restricted access to certain areas to allow grass regrowth, or the frequency of moving pasture pens) could have a significant impact on the surrounding environment (Sossidou et al., 2011).

Intuitively, individual pastured poultry systems may have only a minimal or acute impact; however, when considered as a whole within a region, these systems, if not managed properly, 
could potentially have an unintentional larger impact depending on the number of birds on pasture. For example, Del Signore (2011) indicated that various humates and minerals added to feed might improve the manure both in the brooder and in the field. However, there was no indication of how the "improvement" in manure would be assessed. Prasai et al. (2018) evaluated the manure of conventionally-raised layer and broiler poultry and found differences in nitrogen, carbon, and water content in manure when fed diets supplemented with three different concentrations $(1,2,4 \%)$ of biochar, bentonite, and zeolite. Biochar is an organic charcoal amended for soil, while bentonite is aluminum phyllosilicate clay, and zeolite is aluminosilicate volcanic ash. Potentially due to an increase in $\mathrm{pH}$, ammonia loss in the manure after 35 days was significantly higher for biochar and zeolite, resulting in $\sim 5 \%$ nitrogen in the biochar and zeolite samples compared to $6 \%$ in the control and bentonite samples. All three biochar concentrations significantly improved carbon concentrations $(35.6,36.6$, and $38.3 \%)$ compared to the control (34.9\%), while the other feed amendments resulted in no change or a reduction in carbon content. In broilers, the 1 and $2 \%$ biochar samples also produced the highest proportion of optimally sized granules $(2-4 \mathrm{~mm})$ for further fertilization. This data suggests that the inclusion of feed supplementation can have an impact on the quality of manure used for composting and can reduce the overall need for additional fertilizers which can improve sustainability of the farm. Organic Biochar may be useful in pastured poultry systems; however, there is concern that it can only be used as a feed additive in high-end markets as the April 2019 price point is \$1.29/lbs Biochar (Porter and Laird, 2019).

Importantly, additional studies may indicate that growing poultry on pasture improves soil quality and poses little threat to natural resources as indicated by advocates of pastured poultry production (Risse et al., 2006). Thus, further environmental research and documentation should either confirm the environmental sustainability of these systems or at least provide economically feasible recommendations for maintaining and possibly improving the quality of proximal surface and groundwater resources. Also, recommendations for best practices for small- and medium-sized farms can fully utilize the significant environmental benefits that pastured poultry systems offer such as: improving pasture quality, reduction in the amount of grain needed as feed, and recycling of nutrients.

O'Bryan et al. (2017) investigated the use of best management practices (BMPs) of pastured poultry and their impact on nitrogen and phosphorus loads in the environments. Three farms that processed poultry on-site were investigated over a 9 month period. Additionally, two facilities were investigated over a 3 month period that utilized a mobile poultry processing unit (MPPU). These processing units and alternative poultry processing are described in detail in Micciche et al. (2018a), Rothrock et al. (2019), and O'Bryan et al. (2014). Monthly collection of soil, compost (i.e., from on farm processing), and waste water samples was conducted. Both nitrogen and phosphorus levels varied between locations and also due to seasonal variation. For composting, the highest concentration of nitrogen was $22 \mathrm{mg} / \mathrm{L}$ and the highest for phosphorus was 27 $\mathrm{mg} / \mathrm{L}$ with both nutrient levels being far below the recommended levels for composting ( 20,000 mg/L N and P) (Pace et al., 1995). Conventional poultry processing compost typically has nitrogen levels of 29,000 mg/L and phosphorus levels of $\sim 19,000 \mathrm{mg} / \mathrm{L}$ (Murphy and Handwerker, 1988). In the MPPU that was tested by Plumber and Kiepper (2011), the scalder wastewater nitrogen was more than 10 times lower than conventional scalding water. These data seem to indicate that pastured poultry processed onsite may not drastically impact environmental phosphorus and nitrogen loads. However, these data are difficult to compare due to the limited production scale as O'Bryan et al. (2017) indicated that these farms produced $<1,000$ pastured birds a year.

Vegetative buffers have also been utilized to control nutrient runoff into bodies of water (Tate et al., 2000, 2006). A fescue (Festuca arundinacea) vegetative filter strip ( 0.7 by $1.5 \mathrm{~m})$ placed $0.7 \mathrm{~m}$ from a collection point was shown to improve nutrient retention during simulated rainfall when compared to a continuously cultured fallow (CCF) (Blanco-Canqui et al., 2004). Organic nitrogen loss was $4.06 \mathrm{~kg} / \mathrm{hectare}$ (ha) in the CCF control compared to $1.81 \mathrm{~kg} / \mathrm{ha}$ when using the fescue barrier. The loss of $\mathrm{NO}_{3}, \mathrm{NH}_{4}$, and $\mathrm{PO}_{4}$ in the CCF control was $0.56,1.90$, and $0.74 \mathrm{~kg} / \mathrm{ha}$, respectively compared to 0.43 , 1.49 , and $0.49 \mathrm{~kg} / \mathrm{ha}$ in the fescue barrier. When placed $8 \mathrm{~m}$ from the collection point or in combination with switchgrass (Panicum virgatum), this retention was even higher. While no specific research has been done with pastured poultry production to date, vegetative buffers have been utilized to control nutrient runoff from pastures amended with poultry litter in Chaubey et al. (1995). Fescue plots of 1.5 by $24.4 \mathrm{~m}$ were amended with $5 \mathrm{Mg} / \mathrm{ha}$ and runoff from simulated rainfall was collected after being run through vegetative filters at lengths of $0,3,6,9$, 15 , and $21 \mathrm{~m}$ long. These filters were generated from the same fescue but not amended with manure. Compared to the $0 \mathrm{~m}$ control, the vegetative buffer at $3 \mathrm{~m}$ significantly reduced total Kjeldahl nitrogen (TKN), $\mathrm{NH}_{3}, \mathrm{NO}_{3}$, total phosphorus, $\mathrm{PO}_{4}$, total suspended solids, and chemical oxygen demand in the runoff $(P<0.05)$. The TKN in the $0 \mathrm{~m}$ control was 26.5 and 6.88 $\mathrm{mg} / \mathrm{L}$ in the $3 \mathrm{~m}$ strip where the total phosphorus loads were $6.72 \mathrm{mg} / \mathrm{L}$ in the control compared to $2.22 \mathrm{mg} / \mathrm{L}$. The nitrogen and phosphorus loads were significantly reduced again when using $15 \mathrm{~m}$ of buffer compared to the $3 \mathrm{~m}$ buffer. The runoff after $15 \mathrm{~m}$ of vegetative buffer had a TKN of 1.85 and 0.28 $\mathrm{mg} / \mathrm{L}$ of phosphorus. These data indicate that vegetative strips can be utilized to effectively reduce nutrient runoff from poultry litter and should theoretically be effective against poultry manure within pastured poultry management systems.

\section{ECONOMIC CONSIDERATIONS FOR ENVIRONMENTAL MANAGEMENT OF PASTURED POULTRY SYSTEMS}

Of course, the economic viability of farms is impossible without sustained profits for farmers; therefore, the development of an interactive budgeting tool specific to pastured poultry producers is needed. This tool should allow producers to better understand where they may save costs, increase revenues or both, through, for example, the selection of a different meat type bird or 
by implementing a BMP which may increase the productivity of their pasture. Moyle et al. (2014) and Castellini et al. (2012) provided information on the profitability potential by breed as well as an assessment of various parameters including production, mortality, other health issues, input costs, and behavior. In this research project, farmers took the lead and not only gave evidence-based data, but also provided anecdotal information about their preferences for one breed over another. Overall, even though the conventional Cornish Rock Cross exhibited the lowest input cost, the alternative breeds were found to be more sustainable and better suited (e.g., aggressive foragers with lower mortality) on pasture. They suggested that other pastured poultry farmers could use this as a marketing tool for their product, though a need for consumer education about the product difference was cited as a key for this to be used as a successful marketing tool.

A survey of APPPA members revealed that one of the greatest challenges faced by pastured poultry producers are high costs associated with sourcing high-quality feed (APPPA, 2011; Elkhoraibi et al., 2017). In addition, the APPPA survey data showed that many farmers did not know what their gross income from poultry was, which indicates the need for a simple, interactive budgeting tool. Pastured poultry enterprise budgets can assist producers in better planning and financial decisions by allowing for the comparisons amongst total costs, gross revenues, and net returns from various production practices. Poultry enterprise budgets exist, but few focus on pasture-based production (Certified Investor Agent Specialist (CIAS), 2003; Kansas Rural Center, 2003; Ennis et al., 2008). The budgets that do exist for pastured poultry enterprises, however, are currently not in interactive format, thus limit the ability for straightforward comparisons of marginal changes in animal numbers or production practices that can highlight potential areas of added revenue or cost to the producer.

\section{Indirect Benefits of Environmental Management Within Pastured Poultry Systems}

Aside from economic benefits, pastured poultry systems also promote animal well-being by allowing birds to express natural behaviors such as foraging and dust bathing and decreasing the prevalence of diseases and disorders (e.g., congestive heart failure, leg pathologies, and skeletal conditions) associated with conventional broilers through selection of less susceptible, slow to medium growing breeds (Julian, 2004; Mench, 2004). Currently, the majority of pastured poultry producers raise Cornish Crosses (i.e., fast-growing, conventional breed) as opposed to slower growing breeds (APPPA, 2011; Elkhoraibi et al., 2017). The reason for this appears to be three-fold: feed conversion rates along with the high cost of feed and availability of breeds through nearby hatcheries. However, poultry breed may need to be considered more in the future. Fast-growing broilers, for example, tend to sit and eat with little activity thus not making use of the forage resource available on pasture (Nielsen et al., 2003).
Source of pasture forage may also be a factor in determining economic benefit. Fanatico (2010) investigated various forages for pastured poultry, and a recommendation of one type of forage over another could impact how poultry utilize the pasture (Mattocks, 2002). In addition, they determined the impact of pasture enrichments (i.e., shade, roosts, shelter) on poultry grazing behaviors and found that the addition of enrichments encourages the bird to use the land more evenly. Pastures of clover, grass, and alfalfa did not significantly impact the fatty acid or vitamin A composition of eggs produced by reared hens (Karsten et al., 2010); however, grass-based pastures did statistically improve the Vitamin E concentration (11.8 vs. 9.6 IU/100 g egg yolk) $(P<0.05)$. This was in combination with a $70 \mathrm{~g} / \mathrm{bird} /$ day hen mash supplementation. When compared to caged-hens, eggs from grass-pastured hens contained 2-fold more vitamin E (11.5 vs. $5.5 \mathrm{IU} / 100 \mathrm{~g}$ egg yolk), 2.5-fold more omega-3 fatty acids (3.03 vs. $1.28 \%$ ), and half the ratio of omega-6: omega-3 fatty acids $(5.70$ vs. 12.05$)(P<0.05)$. As a consequence, pasture production poultry may provide a more nutritionally complete and higher valued product depending on the pasture contents; however, further studies are needed to confirm this.

In the long-term, increasing the sustainability of pastured poultry production through the implementation of BMPs and access to simple, user-friendly budgeting tools can enhance the quality of life in rural communities and strengthen these economies (Hilchey et al., 2008). A survey and focus group discussion conducted by Cornell University's Community and Rural Development Institute (CARDI) in 2008 reported that a significant portion of participants expressed a willingness to support family farms near where they live (Hilchey et al., 2008). In addition, participants felt it was important to have agriculture in their communities for social, environmental, and economical reasons. Of the non-economic reasons, agriculture most frequently cited as "contributing to quality of life in the community." It is conceivable that additional research findings may indeed indicate that pastured poultry production can be a positive impact on rural, and even urban, communities.

\section{FUTURE DIRECTIONS}

By providing pastured poultry producers with comprehensive data that will both protect the environment and enhance productivity, U.S. agriculture can be improved through sustainable means. Rainey et al. (2011) found that $71 \%$ of those surveyed in Arkansas found believed locally sourced organic food to be safer than conventional foods. Alternative local markets for free-range or pastured poultry production have increased in the last 5 years (Agricultural Marketing Resource Center Iowa State University (AgMRC), 2018). Even though some farmers have been growing pastured poultry for more than 20 years (Stevenson and Schuster, 2003), more researchbased information is needed that accurately measure the social, economic, and environmental sustainability of pasture-based poultry production (both small and large producers). This type 
of information could be vital for educating and marketing these pastured poultry products to consumers.

However, mitigating the potential environmental impacts of their production systems must be understood. For the most part, pastured poultry production systems (i.e., day range, moveable pens, and free-range) used by producers across the U.S. are relatively similar; thus, the environmental lessons learned and the budgeting tool resulting from such research efforts would be generally applicable (Sustainable Agriculture Research and Education (SARE), 2012). In addition, information on pasture management and methods of cost control would economically benefit pastured poultry enterprises. Therefore, the development of an interactive pastured poultry budget with a variety of inputs including those for feed, breed type, and BMPs is an important, yet missing, piece for the growth of pastured poultry enterprises and would greatly benefit producers across the U.S. Documentation of the environmental impacts and possible benefits may also help enhance labeling of pastured poultry as a "green" product.

The economic component will also need to be addressed by developing budgeting tools for producers to estimate any economic tradeoffs between choices of breeds (e.g., concerning their revenues in the market place) and choices of BMPs. Although pastured poultry enterprise budgets exist, currently there are no interactive budgets that allow for these comparisons under multiple input and market price scenarios.

With respect to the environment, there is a need for information on how different pastured poultry production systems (i.e., bird density, mobile pens vs. day range, breed selection) potentially impact proximal watersheds by runoff of nutrients and microorganisms deposited on pasture. Optimal management systems and breed combinations need to be identified to assist both current and future producers in selecting the most appropriate system and breed for their pasture. Moreover, pasture flock farmers need to know how their current practices impact the environment. More scientific evidence is needed to effectively support the "environmentally friendly" perception of pastured poultry farming. This knowledge gap can be met through the establishment of baseline environmental data and eventual incorporation into Life Cycle Analyses (LCA) for generating management models to optimize production practices. Life cycle analysis or assessments allows environmental impacts to be evaluated during the generation of a product (EPA, 2016). By performing an LCA on the impacts of mitigation strategies in pasture flock production, the need and value of these systems can be fully assessed.

Finally, the social and quality of life impact of pastured poultry production could be addressed by providing some baseline estimates of the potential public health benefits of reduced microbial and nutrient runoff into waterways within a community. If such benefits are then promoted by the farmer or

\section{REFERENCES}

Adrizal, A., Patterson, P. H., Hulet, R. M., Bates, R. M., Myers, C. A. B., Martin, G. P., et al. (2008). Vegetative buffers for fan emissions from poultry farms: 2. ammonia, dust and foliar nitrogen. pastured poultry groups such as APPPA as part of their market brand, this type of information may very well-translate into increased demand for pastured poultry products, thus increasing economic returns for the producer.

\section{CONCLUSIONS}

Overall, research specific to pastured poultry production has focused primarily on implementation of pastured poultry and alternative processing systems, evaluation of broiler breeds, and supplemental feed to reduce grain consumption. However, the environmental impacts of pastured poultry production systems or the economic value of understanding and mitigating these potential impacts for the producer are still issues to be determined.

It appears that the consumer popularity for pasture flock produced poultry meat products will continue to expand, and the impact of these operations on their surrounding environments will need to be assessed. This may be particularly critical in geographical regions where pasture flocks are in close proximity with large municipalities. In these situations, the typical environmental concerns issues such as shared water sources and impact on ground water quality will need to be considered.

As pasture poultry operations continue to develop some of the increased profit, attributed to an increased sales price, will need to be utilized to ensure local environmental safety particularly to watershed areas. Due to pasture poultry typically sold as organic, there is a need to ensure environmental safety that cannot be mediated with conventional chemical sanitation. While alternative safety techniques are being developed (Micciche et al., 2018a), physical barriers offer a cost-efficient methodology of protecting local watersheds, provided land is plentiful. In areas where physical barriers are not practical additional systematic farm to fork management tools and programs will need to be developed and implemented to ensure that environmental impacts are mitigated in a cost-effective manner. This will mean that environmental baseline data will have to be generated and analyzed to determine which production factors are most critical to achieve efficient and economical mitigation practices.

\section{AUTHOR CONTRIBUTIONS}

All authors listed have made a substantial, direct and intellectual contribution to the work, and approved it for publication.

\section{FUNDING}

AM was supported by a Distinguished Doctoral Fellowship and supported from the Department of Food Science at the University of Arkansas. 
Alali, W. Q., Thakur, S., Berghaus, R. D., Martin, M. P., and Gebreyes, W. A. (2010). Prevalence and distribution of Salmonella in organic and conventional broiler poultry farms. Foodborne Pathog. Dis. 7, 1363-1371. doi: 10.1089/fpd.201 0.0566

American Pasture Poultry Production Association (APPPA) (2019). Where to Buy Pasture Raised Chicken, Eggs, Turkeys, and Other Poultry. Retrieved from: https://www.apppa.org/Directory (accessed May 17, 2019).

APPPA (2011). Farmer Member Survey. (personal communication)\$\$

Arnone, R. D., and Walling, J.P. (2007). Waterborne pathogens in urban watersheds. J. Water Health 5, 149-162. doi: 10.2166/wh.2006.001

Aschemann-Witzel, J., and Zielke, S. (2017). Can't buy me green? A review of consumer perceptions of and behavior toward the price of organic food. J. Consum. Aff. 51, 211-251. doi: 10.1111/joca.12092

Atherholt, T. B., LeChevallier, M. W., Norton, W. D., and Rosen, J. S. (1998). Effect of rainfall on Giardia and Crypto. J. Am. Water Works Assoc. 90, 66-80. doi: 10.1002/j.1551-8833.1998.tb08499.x

Avrain, L., Humbert, F., L'Hospitalier, R., Sanders, P., Vernozy-Rozand, C., and Kempf, I. (2003). Antimicrobial resistance in Campylobacter from broilers: association with production type and antimicrobial use. Vet. Microbiol. 96, 267-276. doi: 10.1016/j.vetmic.2003.07.001

Bailey, J. S., and Cosby, D. E. (2005). Salmonella prevalence in freerange and certified organic chickens. J. Food Protect. 68, 2451-2453. doi: 10.4315/0362-028X-68.11.2451

Berg, C. (2001). Health and welfare in organic poultry production. Acta Vet. Scand. 43:S37. doi: 10.1186/1751-0147-43-S1-S37

Blanco-Canqui, H., Gantzer, C. J., Anderson, S. H., Alberts, E. E., and Thompson, A. L. (2004). Grass barrier and vegetative filter strip effectiveness in reducing runoff, sediment, nitrogen, and phosphorus loss. Soil Sci. Soc. Am. J. 68, 1670-1678. doi: 10.2136/sssaj2004.1670

Boggia, A., Paolotti, L., and Castellini, C. (2010). Environmental impact evaluation of conventional, organic and organic-plus poultry production systems using life cycle assessment. World Poult. Sci. J. 66, 95-114. doi: $10.1017 /$ S0043933910000103

Bradford, S. A., Morales, V. L., Zhang, W., Harvey, R. W., Packman, A. I., Mohanram, A., et al. (2013). Transport and fate of microbial pathogens in agricultural settings. Crit. Rev. Environ. Sci. Tech. 43, 775-893. doi: 10.1080/10643389.2012.710449

Braeye, T., De Schrijver, K., Wollants, E., Van Ranst, M., and Verhaegen, J. (2015). A large community outbreak of gastroenteritis associated with consumption of drinking water contaminated by river water, Belgium, 2010. Epidemiol. Infect. 143, 711-719. doi: 10.1017/S0950268814001629

Burley, H. K., Adrizal, A., Patterson, R. M., Hulet, H., Lu, R. M., Bates, G. P., et al. (2011). The potential of vegetative buffers to reduce dust and respiratory virus transmission from commercial poultry farms. J. Appl. Poult. Res. 20, 210-222. doi: 10.3382/japr.2010-00298

Carpenter, S. R., Caraco, N. F., Correll, D. L., Howarth, R. W., Sharpley, A. N., and Smith, V. H. (1998). Nonpoint pollution of surface waters with phosphorus and nitrogen. Ecol. Appl. 8, 559-568. doi: 10.1890/10510761(1998)008[0559:NPOSWW]2.0.CO;2

Castellini, C., Boggia, A., Cortina, C., Dal Bosco, A., Paolotti, L., Novelli, E., et al. (2012). A multicriteria approach for measuring the sustainability of different poultry production systems. J. Clean. Prod. 37, 192-201. doi: 10.1016/j.jclepro.2012.07.006

Certified Investor Agent Specialist (CIAS) (2003). Poultry Enterprise Budget. Available online at: http://www.cias.wisc.edu/crops-and-livestock/poultryenterprise-budget/ (accessed August 30, 2018).

Chaubey, I., Edwards, D. R., Daniel, T. C., Moore, P. A. Jr., and Nichols, D. J. (1995). Effectiveness of vegetative filter strips in controlling losses of surface-applied poultry litter constituents. Transact. ASAE 38, 1687-1692. doi: $10.13031 / 2013.27995$

Clark, C. G., Price, L., Ahmed, R., Woodward, D. L., Melito, P. L., Rodgers, F. G., et al. (2003). Characterization of waterborne outbreak-associated Campylobacter jejuni, Walkerton, Ontario. Emerg. Infect. Dis. 9, 1232-1241. doi: 10.3201/eid0910.020584

Colles, F. M., Jones, T. A., McCarthy, N. D., Sheppard, S. K., Cody, A. J., Dingle, K. E., et al. (2008). Campylobacter infection of broiler chickens in a free-range environment. Environ. Microbiol. 10, 2042-2050. doi: $10.1111 / j .1462-2920.2008 .01623 . x$
Del Signore, C. (2011). Farmer/Rancher Project: "Feeding Minerals and Supplements to an Organic Pastured Poultry Operation". Available online at: https://projects.sare.org/sare_project/fne11-712/ (accessed August 30, 2018).

DeLaune, P. B., and Moore, P. A. (2016). Copper and zinc runoff from land application of composted poultry litter. J. Environ. Qual. 45, 1565-1571. doi: 10.2134/jeq2015.09.0499

DeLaune, P. B., Moore, P. A., and Lemunyon, J. L. (2006). Effect of chemical and microbial amendment on phosphorus runoff from composted poultry litter. J. Environ. Qual. 35, 1291-1296. doi: 10.2134/jeq2005.0398

Dittoe, D. K., Ricke, S. C., and Kiess, A. S. (2018). Organic acids and potential for modifying the avian gastrointestinal tract and reducing pathogens and disease. Front. Vet. Sci. 5:216. doi: 10.3389/fvets.2018.00216

Dosskey, M. G. (2002). Setting priorities for research on pollution reduction functions of agricultural buffers. Environ. Manage. 30, 641-650. doi: 10.1007/s00267-002-2755-y

Edge, T. A., El-Shaarawi, A., Gannon, V., Jokinen, C., Kent, R., Khan, I. U. H., et al. (2012). Investigation of an Escherichia coli environmental benchmark for waterborne pathogens in agricultural watersheds in Canada. J. Environ. Qual. 41, 21-30. doi: 10.2134/jeq2010.0253

Eilperin, J. (2006). Pollution in the Water, Lawsuits in the Air. The Washington Post. Available online at: http://www.washingtonpost.com/wp-dyn/content/ article/2006/08/27/AR2006082700849.html (accessed March 15, 2018).

Elkhoraibi, C., Pitesky, M., Dailey, N., and Niemeier, D. (2017). Operational challenges and opportunities in pastured poultry operations in the United States. Poult. Sci. 96, 1648-1650. doi: 10.3382/ps/pew448

Ennis, K. N., Jefferson-Moore, K. Y., and Bynum, J. S. (2008). The Economic Feasibility of Producing Pasture Poultry for Limited Resource Farmers in Southeastern North Carolina.

EPA (2016). Design for the Environment Life-Cycle Assessments [Online]. Available online at: https://www.epa.gov/saferchoice/design-environment-lifecycle-assessments (accessed June 25, 2019).

Esteban, J. I., Oporto, B., Aduriz, G., Juste, R. A., and Hurtado, A. (2008). A survey of food-borne pathogens in free-range poultry farms. Int. J. Food Microbiol. 123, 177-182. doi: 10.1016/j.ijfoodmicro.2007.12.012

Evans, A. E., Mateo-Sagasta, J., Qadir, M., Boelee, E., and Ippolito, A. (2019). Agricultural water pollution: key knowledge gaps and research needs. Curr. Opin. Environ. Sustainability 36, 20-27. doi: 10.1016/j.cosust.201 8.10 .003

Fanatico, A. (2010). Annual Report: "Integrating Free Range Poultry with Ruminant and Agroforestry Production in a Systems Approach". Available online at: https:// projects.sare.org/sare_project/ls10-226/ (accessed August 30, 2018).

Fanatico, A. C. (2006). Alternative Poultry Production Systems and Outdoor Access. Fayetteville, AR: ATTRA publication; National Center for Appropriate Technology.

Ferguson, C. M., Davies, C. M., Kaucner, C., Ashbolt, N. J., Krogh, M., Rodehutskors, J., et al. (2007). Field scale quantification of microbial transport from bovine faeces under simulated rainfall events. J. Water Health 5, 83-95. doi: $10.2166 /$ wh. 2006.050

Foster, K. (2019). We Compared the Prices for Whole Chickens and Individual Pieces-Here's What We Found. Retrieved from: https://www.thekitchn. com/whole-chicken-price-versus-individual-pieces-255821 (accessed June 10, 2019)

Fox, G. A., Matlock, E. M., Guzman, J. A., Sahoo, D., and Stunkel, K. B. (2011). Escherichia coli load reduction from runoff by vegetative filter strips: a laboratory-scale study. J. Environ. Qual., 40, 980-988. doi: $10.2134 /$ jeq2010.0391

Frey, S. K., Topp, E., Khan, I. U. H., Ball, B. R., Edwards, M., Gottschall, N., et al. (2015). Quantitative Campylobacter spp., antibiotic resistance genes, and veterinary antibiotics in surface and ground water following manure application: influence of tile drainage control. Sci. Total Environ. 532, 138-153. doi: 10.1016/j.scitotenv.2015.03.114

Fukumoto, G. K., and Replogle, J. R. (1999). Pastured Poultry Production: An Evaluation of its Sustainability in Hawaii. Livestock Management; College of Tropical Agriculture and Human Resources, University of Hawaii.

Gallay, A., De Valk, H., Cournot, M., Ladeuil, B., Hemery, C., Castor, C., et al. (2006). A large multi-pathogen waterborne community outbreak linked to faecal contamination of a groundwater system, France, 2000. Clin. Microbiol. Infect. 12, 561-570. doi: 10.1111/j.1469-0691.2006.01441.x 
Gast, R. K. (2007). Serotype-specific and serotype-independent strategies for preharvest control of food-borne Salmonella in poultry. Avian Dis. 51, 817-828. doi: 10.1637/8090-081807.1

Gibson, K. E., Lee, J., Jackson, J. M., Smith, L. N., and Almeida, G. (2017). Identification of factors affecting fecal pollution in beaver lake reservoir. $J$. Environ. Qual. 46, 1048-1056. doi: 10.2134/jeq2017.03.0105

Gilpin, B. J., Scholes, P., Robson, B., and Savill, M. G. (2008). The transmission of thermotolerant Campylobacter spp. to people living or working on dairy farms in New Zealand. Zoonoses Public Health 55, 352-360. doi: $10.1111 /$ j.1863-2378.2008.01142.x

Grandin, T. (2019). "Principles for commercial supply chain managers of livestock and poultry," in Sustainable Meat Production and Processing, ed C. Galanakis (Cambridge, MA: Academic Press), 1-15.

Hanning, I., Biswas, D., Herrera, P., Roesler, M., and Ricke, S. C. (2010). Prevalence and characterization of Campylobacter jejuni isolated from pasture flock poultry. J. Food Sci. 75, 496-502. doi: 10.1111/j.1750-3841.2010. 01747.x

Hilchey, D., Gillespie, G., Kay, D., and Smith, R. D. (2008). The Impact of Agriculture: It's More Than Economic (Part I). Available online at: https:// ecommons.cornell.edu/bitstream/handle/1813/55910/04-2008-RNYM.pdf? sequence $=1$ (accessed August 30, 2018).

Hoogenboom, L. A. P., Bokhorst, J. G., Northolt, M. D., Van de Vijver, L. P. L., Broex, N. J., Mevius, D. J., et al. (2008). Contaminants and microorganisms in Dutch organic food products: a comparison with conventional products. Food Addit. Contam. 25, 1195-1207. doi: 10.1080/02652030802014930

Ismail, A., Shoieb, A., Prasher, S. O., Chénier, M. R., and Patel, R. M. (2016). Evaluation of biochar soil amendments in reducing soil and water pollution from total and fecal coliforms in poultry manure. Canad. Biosyst. Eng. 58, 1.21-1.31. doi: 10.7451/CBE.2016.58.1.21

Julian, R. J. (2004). "Evaluating the impact of metabolic disorders on the welfare of broilers," in: Measuring and Auditing Broiler Welfare, eds C. A. Weeks and A. Butterworth (Wallingford: CABI Publishing Series), 51-59.

Kansas Rural Center (2003). Pasture Poultry Enterprise Budget. Sustainable Agriculture Management Guide. Available online at: http://www. kansasruralcenter.org/publications/PPEntbudget.pdf (accessed August 30, 2018).

Karsten, H. D., Patterson, P. H., Stout, R., and Crews, G. (2010). Vitamins A, E and fatty acid composition of the eggs of caged hens and pastured hens. Renew. Agr. Food Syst. 25, 45-54. doi: 10.1017/S1742170509990214

Kassel (2018). Most Farmers rEceive off-farm Income, But Small-Scale Operators Depend on it. Available online at: https://www.ers.usda.gov/data-products/ chart-gallery/gallery/chart-detail/?chartId=58426 (accessed August 30, 2018).

Kim, S. A., Jang, M. J., Kim, S. Y., Yang, Y., Pavlidis, H. O., and Ricke, S. C. (2019). Potential for prebiotics as feed additives to limit foodborne Campylobacter establishment in the poultry gastrointestinal tract. Front. Microbiol. 10:91. doi: $10.3389 /$ fmicb.2019.00091

Knight, C. A., Anderson,B, G., and Hatley, C., J. (2017). University of Maine Pasture Poultry Project Summer 2017. Available online at: https://extension.umaine. edu/livestock/wp-content/uploads/sites/36/2018/12/UMaine-ExtensionPasture-Poultry-Project-2017.pdf (accessed August 30, 2018).

Kobayashi, A., Sano, D., Hatori, J., Ishii, S., and Okabe, S. (2013). Chickenand duck-associated Bacteroides-Prevotella genetic markers for detecting fecal contamination in environmental water. Appl. Microbiol. Biotechnol. 97, 7427-7437. doi: 10.1007/s00253-012-4469-2

Lapointe, B. E., Herren, L. W., Debortoli, D. D., and Vogel, M. A. (2015). Evidence of sewage-driven eutrophication and harmful algal blooms in Florida's Indian River Lagoon. Harmful Algae 43, 82-102. doi: 10.1016/j.hal.2015.01.004

Lestari, S. I., Han, F., Wang, F., and Ge, B. (2009). Prevalence and antimicrobial resistance Salmonella of serovars in conventional and organic chickens from Louisiana retail stores. J. Food Prot. 72, 1165-1172. doi: 10.4315/0362-028X-72.6.1165

Mattocks, J. (2002). Pastured-raised poultry nutrition. Prepared for Heifer International. Available online at: http://cecentralsierra.ucanr.org/files/122168. pdf (accessed August 30, 2018).

McEwen, S. A., Wilson, T. M., Ashford, D. A., Heegaard, E. D., Kuiken, T., and Kournikakis, B. (2006). Microbial forensics for natural and intentional incidents of infectious disease involving animals. OIE Revue Sci. Tech. 25, 329-339. doi: 10.20506/rst.25.1.1662
Melendez, S. N., Hanning, I., Han, J., Nayak, R., Clement, A. R., Wooming, A., et al. (2010). Salmonella enterica isolates from pasture-raised poultry exhibit antimicrobial resistance and class I integrons. J. Appl. Microbiol. 109, 1957-1966. doi: 10.1111/j.1365-2672.2010.04825.x

Mench, J. A. (2004). "Lameness," in Measuring and Auditing Broiler Welfare, eds C.A. Weeks and A. Butterworth (Wallingford: CABI), 3-18.

Mench, J. A., Sumner, D. A., and Rosen-Molina, J. T. (2011). Sustainability of egg production in the United States-The policy and market context. Poult. Sci. 90, 229-240. doi: 10.3382/ps.2010-00844

Metcalf, J. H., Moore P. A. Jr., Donoghue, K., Arsi, A., Woo-Ming, P. J., Blore, I., et al. (2014). Bacterial content in runoff from simulated rainfall applied to plots amended with poultry litter. Int. J. Poult. Sci. 13, 133-137. doi: 10.3923/ijps.2014.133.137

Micciche, A. C., Foley, S. L., Pavlidis, H. O., McIntyre, D. R., and Ricke, S. C. (2018b). A review of prebiotics against Salmonella in poultry: current and future potential for microbiome research applications. Front. Vet. Sci. 5:191. doi: 10.3389/fvets.2018.00191

Micciche, A. C., Rubinelli, P. M., Wages, J. A., and Ricke, S. C. (2018a). Source of water and potential sanitizers and biological antimicrobials for alternative poultry processing food safety applications. Front. Sustainable Food Syst. 2:82. doi: $10.3389 /$ fsufs. 2018.00082

Moyle, J. R., Arsi, K., Woo-Ming, A., Arambel, H., Fanatico, A., Blore, P. J., et al. (2014). Growth performance of fast-growing broilers reared under different types of production systems with outdoor access: implications for organic and alternative production systems. J. Appl. Poult. Res. 23, 212-220. doi: 10.3382/japr.2013-00882

Murphy, D. W., and Handwerker, T. S. (1988). "Preliminary investigations of composting as a method of dead bird disposal," in Proceedings of the National Poultry Waste Management Symposium. (Columbus, OH: Department of Poultry Science, The Ohio State University), 65-72.

Nayak, B., Weidhaas, J., and Harwood, V. J. (2015). LA35 poultry fecal marker persistence is correlated with that of indicators and pathogens in environmental waters. Appl. Environ. Microbiol. 81, 4616-4625. doi: 10.1128/AEM.00444-15

Nielsen, B. L., Thomsen, M. G., Sorensen, P., and Young, J. F. (2003). Feed and strain effects on the use of outdoor areas by broilers. Br. Poult. Sci. 44, 161-169. doi: 10.1080/0007166031000088389

O’Bryan, C. A., Crandall, P., Jaroni, D., Ricke, S. C., and Gibson, K. E. (2017). Assessment of nitrogen and phosphorus loads present in environments impacted by alternative poultry processing operations utilized in pasture-raised poultry production. Renew. Agr. Food Syst. 32, 33-42. doi: 10.1017/S1742170515000514

O’Bryan, C. A., Crandall, P. G., Davis, M. L., Kostadini, G., Gibson, K. E., Alali, W. Q., et al. (2014). Mobile poultry processing units: a safe and cost-effective poultry processing option for the small-scale farmer in the United States. World Poult. Sci. J. 70, 787-802. doi: 10.1017/S0043933914000853

Pace, M. G., Miller, B. E., and Farrell-Poe, K. L. (1995). The Composting Process. Utah State University-Extension. Available online at: http://digitalcommons. usu.edu/extension_histall/48 (verified February 27, 2015)

Parajuli, P. B., Mankin, K. R., and Barnes, P. L. (2008). Applicability of targeting vegetative filter strips to abate fecal bacteria and sediment yield using SWAT. Agr. Water Manag. 95, 1189-1200. doi: 10.1016/j.agwat.2008.05.006

Pew Environment Group (2011). Big Chicken: Pollution and Industrial poultry production in America. Washington, DC: Pew Charitable Trusts. Available online at: https://www.pewtrusts.org/-/media/legacy/uploadedfiles/ peg/publications/report/pegbigchickenjuly2011pdf.pdf?la=en\&hash= 6F6A5C0C1C3CE4030044B9857FE8BF86FD0E4ED1 (accessed May 20, 2019).

Pierson, S. T., Cabrera, M. L., Evanylo, G. K., Kuykendall, H. A., Hoveland, C. S., McCann, M. A., et al. (2001). Phosphorus and ammonium concentrations in surface runoff from grasslands fertilized with broiler litter. J. Environ. Qual. 30, 1784-1789. doi: 10.2134/jeq2001.3051784x

Pilon, C., Moore, P. A., Pote, D. H., Martin, J. W., and DeLaune, P. B. (2017). Effects of grazing management and buffer strips on metal runoff from pastures fertilized with poultry litter. J. Environ. Qual. 46, 402-410. doi: 10.2134/jeq2016.09.0379

Pitesky, M. (2017). Free-Range vs. Pastured Poultry: What's the Difference? Retrieved from: https://www.hobbyfarms.com/free-range-vs-pasturedpoultry-whats-difference/ (accessed June 10, 2019). 
Plumber, H. S., and Kiepper, B. H. (2011). "Impact of poultry processing byproducts on wastewater generation, treatment, and discharges," in Proceedings of the 2011 Georgia Water Resources Conference, April 11-13, 2011 (Athens, GA: University of Georgia).

Porter, P., and Laird, D. (2019). Biochar: Prospects of Commercialization [Online]. Available online at: https://farm-energy.extension.org/biochar-prospects-ofcommercialization/ (accessed June 15, 2019).

Prasai, T. P., Walsh, K. B., Midmore, D. J., Jones, B. E., and Bhattarai, S. P. (2018). Manure from biochar, bentonite and zeolite feed supplemented poultry: Moisture retention and granulation properties. J. Environ. Manag. 216, 82-88. doi: 10.1016/j.jenvman.2017.08.040

Rainey, R., Crandall, P. G., O’Bryan, C. A., Ricke, S. C., Pendleton, S., and Seideman, S. (2011). Marketing locally produced organic foods in three metropolitan Arkansas farmers' markets: consumer opinions and food safety concerns. J. Agr. Food Inf. 12, 141-153. doi: 10.1080/10496505.2011.563223

Ricke, S. C. (2018). Impact of prebiotics on poultry production and food safety. Yale J. Biol. Med. 91:151.

Risse, L. M., Cabrera, M. L., Franzluebbers, A. J., Gaskin, J. W., John, E., Gilley, R., et al. (2006). "Land application of manure for beneficial reuse," in Animal Agriculture and the Environment, eds J. M. Rice, D. F. Caldwell, and F.J. Humenik (St. Joseph, MI: National Center for Manure and Animal Waste Management White Papers), 283-316.

Rothrock, M. J., Hiett, K. L., Guard, J. Y., and Jackson, C. R. (2016). Antibiotic resistance patterns of major zoonotic pathogens from all-natural, antibioticfree, pasture-raised broiler flocks in the southeastern United States. J. Environ. Qual. 45, 593-603. doi: 10.2134/jeq2015.07.0366

Rothrock, M. J., Micciche, A. C., Bodie, A., and Ricke, S. C. (2019). Listeria occurrence and potential control strategies in alternative and conventional poultry processing and retail. Front. Sustainable Food Syst. 3:33. doi: 10.3389/fsufs.2019.00033

Santamaría, J., and Toranzos, G. A. (2003). Enteric pathogens and soil: a short review. Int. Microbiol. 6, 5-9. doi: 10.1007/s10123-0030096-1

Scott, J. T., Haggard, B. E., Sharpley, A. N., and Romeis, J. J. (2011). Change point analysis of phosphorus trends in the Illinois River (Oklahoma) demonstrates the effects of watershed management. J. Environ. Qual. 40, 1249-1256. doi: $10.2134 /$ jeq2010.0476

Sharpley, A., Daniels, M., Berry, L., Hallmark, C., and Riley, L. (2016). Proactive stakeholder program measures on-farm effectiveness of conservation practices that reduce fertilizer and manure nutrient loss. Better Crops Plant Food $100,13-15$.

Sharpley, A. N., Daniels, M. B., Slaton, N. A., Berry, L., Burk, J., Hallmark, C., et al. (2018). "Monitoring potassium losses in runoff on arkansas discovery farms: preliminary findings," in Arkansas Soil Fertility Studies, Vol. 35, ed. N. A. Slaton (Fayetteville, AR: Arkansas Agricultural Experiment Station).

Sharpley, A. N., Herron, S., and Daniel, T. (2007). Overcoming the challenges of phosphorus-based management in poultry farming. J. Soil Water Conserv. $62,375-389$.

Sharpley, A. N., Kleinman, P. J., Jordan, P., Bergström, L., and Allen, A. L. (2009). Evaluating the success of phosphorus management from field to watershed. J. Environ. Qual. 38, 1981-1988. doi: 10.2134/jeq2008.0056

Siemon, C. E., Bahnson, P. B., and Gebreyes, W. A. (2007). Comparative investigation of prevalence and antimicrobial resistance of Salmonella between pasture and conventionally reared poultry. Avian Dis. 51, 112-117. doi: 10. 1637/0005-2086(2007)051[0112:CIOPAA]2.0.CO;2

Sims, J. T. (1997). "Agricultural and environmental issues in the management of poultry wastes: recent innovations and long-term challenges," in Uses of byProducts and Wastes in Agriculture, eds J. Rechcigl and H. C. MacKinnon (Washington, DC: Am. Chem. Soc), 72-90.

Slaton, N. A., Brye, K. R., Daniels, M. B., Daniel, T. C., Norman, R. J., and Miller, D. M. (2004). Nutrient input and removal trends for agricultural soils in nine geographic regions in Arkansas. J. Environ. Qual. 33, 1606-1615. doi: $10.2134 /$ jeq2004.1606

Sossidou, E. N., Dal Bosco, A., Elson, H. A., and Fontes, C. M. G. A. (2011). Pasture-based systems for poultry production: implications and perspectives. World Poult. Sci. J. 67, 47-58. doi: 10.1017/S0043933911000043

Soupir, M. L., Mostaghimi, S., Yagow, E. R., Hagedorn, C., and Vaughan, D. H. (2006). Transport of fecal bacteria from poultry litter and cattle manures applied to pastureland. Water Air Soil Pollut. 169, 125-136. doi: $10.1007 / \mathrm{s} 11270-006-1808-\mathrm{x}$

Stevenson, S., and Schuster, D. (2003). Large-scale pastured poultry farming in the U.S. Center for Integrated Agricultural Systems, University of Wisconsin-Madison (Research Brief \#63). Madison, WI: UW-Madison Center for Integrated Agricultural Systems.

Sustainable Agriculture Research and Education (SARE) (2012). Profitable Poultry. Available online at: https://www.sare.org/Learning-Center/Bulletins/ Profitable-Poultry (accessed May 20, 2019).

Tate, K. W., Atwill, E. R., Bartolome, J. W., and Nader, G. (2006). Significant Escherichia coli attenuation by vegetative buffers on annual grasslands. J. Environ. Qual. 35, 795-805. doi: 10.2134/jeq2005.0141

Tate, K. W., Nader, G. A., Lewis, D. J., Atwill, E. R., and Connor, J. M. (2000). Evaluation of buffers to improve the quality of runoff from irrigated pastures. J. Soil Water Conserv. 55, 473-478.

Trimble, L. M., Alali, W. Q., Gibson, K. E., Ricke, S. C., Crandall, P., Jaroni, D., et al. (2013). Salmonella and Campylobacter prevalence and concentration on pasture-raised broilers processed on-farm, in a Mobile Processing Unit, and at small USDA-inspected facilities. Food Control 34, 177-182. doi: 10.1016/j.foodcont.2013.04.024

U.S. Environmental Protection Agency (2010). Watershed Assessment, Tracking and Environmental Results. Available online at: https://iaspub.epa.gov/ waters10/attains_nation_cy.control?p_report_type $=\mathrm{T}$ (accessed on May 20, 2019).

USDA/ERS (2011). USDA Small Farm Definitions. Available online at: http://www. extension.org/pages/13823/usda-small-farm-definitions (accessed November 4, 2018).

USDA/NASS (2019). Poultry: Production and Value. 2018 Summary. (Washington, DC: U.S. Department of Agriculture). Available online at: http://usda.mannlib. cornell.edu/usda/current/PoulProdVa/PoulProdVa-04-28-2011.pdf (accessed September 30, 2018).

Van Loo, E. J., Alali, W., and Ricke, S. C. (2012). Food safety and organic meats. Ann. Rev. Food Sci. Tech. 3, 203-225. doi: 10.1146/annurev-food-022811-101158

Van Loo, E. J., Caputo, V., Nayga, R. M. Jr., Meullenet, J. F., and Ricke, S. C. (2011). Consumers' willingness to pay for organic chicken breast: evidence from choice experiment. Food Qual. Pref. 22, 603-613. doi: 10.1016/j.foodqual.2011.02.003

Vereen, E., Lowrance, R. R., Jenkins, M. B., Adams, P., Rajeev, S., and Lipp, E. K. (2013). Landscape and seasonal factors influence Salmonella and Campylobacter prevalence in a rural mixed-use watershed. Water Res. 47, 6075-6085. doi: 10.1016/j.watres.2013.07.028

Vories, E. D., Costello, T. A., and Glover, R. E. (2001). Runoff from cotton fields fertilized with poultry litter. Trans. ASAE 44, 1495-1502. doi: 10.13031/2013.7032

Weidhaas, J. L., Macbeth, T. W., Olsen, R. L., and Harwood, V. J. (2011). Correlation of quantitative PCR for a poultry-specific Brevibacterium marker gene with bacterial and chemical indicators of water pollution in a watershed impacted by land application of poultry litter. Appl. Environ. Microbiol. 77, 2094-2102. doi: 10.1128/AEM.02555-10

Winkworth, C. L., Matthaei, C. D., and Townsend, C. R. (2008). Recently planted vegetation strips reduce Giardia runoff reaching waterways. J. Environ. Qual. 37, 2256-2263. doi: 10.2134/jeq2008.0045

Wong, W. H., Dudula, J. J., Beaudoin, T., Groff, K., Kimball, W., and Swigor, J. (2018). Declining ambient water phosphorus concentrations in Massachusetts' rivers from 1999 to 2013: environmental protection works. Water Res. 139, 108-117. doi: 10.1016/j.watres.2018.03.053

Conflict of Interest Statement: The authors declare that the research was conducted in the absence of any commercial or financial relationships that could be construed as a potential conflict of interest.

Copyright $\odot 2019$ Rothrock, Gibson, Micciche and Ricke. This is an open-access article distributed under the terms of the Creative Commons Attribution License (CC $B Y)$. The use, distribution or reproduction in other forums is permitted, provided the original author(s) and the copyright owner(s) are credited and that the original publication in this journal is cited, in accordance with accepted academic practice. No use, distribution or reproduction is permitted which does not comply with these terms. 